\title{
Pohřbívání uvnitř a vně kostelů - brněnské kostelní pohřby v době 17.-18. století
}

\author{
Michaela Králíková \\ Do redakce doručeno 12. září 2011; k publikaci přijato 15. října 2011
}

\begin{abstract}
BURIALS INSIDE AND OUTSIDE CHURCHES - CHURCH FUNERALS IN BRNO DURING THE $17^{\mathrm{TH}}-18^{\mathrm{TH}}$ CENTURY
ABSTRACT This article introduces human burial methods around and inside the churches of the 17th-18th century. It is about funerals near and inside churches, which can be seen in the form of memorial stones located on church walls or as paving stones sealing entrances to underground tombs and crypts. After a general introduction outlining the history and development of church burial space, the study introduces burials in cemeteries and churches from $13^{\text {th }}$ to $18^{\text {th }}$ century in the Moravian metropolis - Brno. More precisely, the attention is focused on one of the Brno's dominant features - the Cathedral of St. Peter and Paul, where archaeological research has so far confirmed its former significance as a collegiate chapter and diocesan church.
\end{abstract}

KEY WORDS church; churchyard; grave; crypt; burial; devotionalies; Brno

ABSTRAKT Příspěvek seznamuje se způsobem pohřbívání člověka v době 17. a 18. století. Jedná se o pohřby okolo a především uvnitř kostelů, jejichž doklady můžeme spatřit v podobě náhrobníků umístěných na kostelních stěnách či v podobě dlažebních kamenů, zakrývajících vstupy do podzemních hrobek a krypt. Po obecném vstupu, přibližujícím historii a vývoj kostelních pohřbů, seznamuje studie se situací pohřbů na hřbitovech a v kostelech moravské metropole - Brna, a to zhruba od 13. do 18. století. Úžeji je pozornost zaměřena na jednu z brněnských dominant - katedrálu sv. Petra a Pavla, kde archeologický výzkum jen potvrdil její někdejší význam jako kolegiátní kapituly a diecézního chámu.

KLÍČOVÁ SLOVA kostel, hřbitov, hrob, krypta, pohřeb, devocionálie, Brno

\section{VÝVOJ POHŘBŮ V EXTERIÉRU A INTERIÉRU KOSTELA}

Pohřbívání v blízkosti kostela či lépe přímo v kostele byl lákadlem pro smrtelníky již od nejstarších křestanských dob. Každý chtěl být po smrti ochraňován svatými a tudíž se snažil spočinout po smrti v jejich blízkosti. Dalším důvodem bylo obětování při mších $-\mathrm{z}$ těchto důvodů byla nejoblíbenější místa v kněžišti poblíž oltáře, ta byla ovšem také nejdražší. Na našem území se hřbitovy začaly přesouvat ke kostelním stavbám krátce poté, co se kostelní stavby začaly budovat, tedy již v 9. století. Uplatňoval se tak křestanský pohřební ritus, který se $\mathrm{v}$ průběhu následujících staletí víceméně posiloval a přetrval až do období novověku. Tehdy se nejrozšířenějším ve střední Evropě stal katolický pohřební ritus. Byl určován a řízen jak církevními tak státními předpisy, které reagovaly na měnící se náboženskou, politickou a hospodářskou situ- aci. Místo a způsob uložení mrtvého, ale také jeho pohřební výbava, byly ovlivněny společenským a sociálním postavením jedince, jeho náboženským vyznáním, popřípadě etnicitou. V kostelních hrobech a kryptách byli pohřbíváni v prvé řadě osoby duchovní, včetně př́slušníků mužských i ženských církevních řádů, dále panovníci, příslušníci šlechtických rodů a vysocí hodnostáři, také zakladatelé kostelů, klášterů a jejich fundátoři, učitelé a rektoři v kolejích (srov. Ariès 2000, I., 66, Bednárik 1972, 115, Unger 2006, 48-96). I když zde byla snaha ze strany církve omezit pohřby uvnitř kostelů, platilo, že porušování zákazů je výsadou mocných, bohatých a urozených. Od 17. století, kdy se pohřby v kostele staly ještě více populární, byly vedle zmíněných osob pohřbívány také osoby světské, například nižší šlechta nebo zámožní měštané, kteří si místo předplatili. Stále více byly kostelní hroby zřizovány především $z$ důvodu prestiže rodiny a demonstrace majetkové a sociální úspěšnosti. $Z$ těchto důvodů se rozšíril v novověku 
také zvyk pokřbívat do tzv. krypt - podzemních prostor, jež původně sloužily výhradně pro uctívání relikvií mučedníků (Fingerlin 1992, 207). Přeplňování kostelních hrobek však přispívalo k šíření různých chorob a epidemií, proto císař Josef II. svými dekrety z roku 1783 až 1785 (srov. Kunc 1937, 51, Navrátilová 1998, 155) zakázal nadále pohřbívat v kostelech. Tato opatření vedla $\mathrm{k}$ výstavbě rodinných hrobů a hrobek, často situovaných v kaplích na hřbitovech oddělených od kostelů a přesunutých na okraje měst nebo na pozemcích v blízkosti obývaného domu.

$\mathrm{Na}$ vymezeném a posvěceném prostoru u farních hřbitovů se pohřbívalo již od středověku. Avšak až koncem 17. století, díky prosazovaným hygienickým opatřením, začal hřbitov sloužit výhradně k pohřebním účelům. Přibývající množství lidí, především ve městech, nutilo již koncem 16 . století zakládat nové hřbitovy. Už v této době tedy dochází $\mathrm{k}$ přesunu hřbitovů mimo město. Staré hřbitovy však zůstaly a pokud bylo místo, pohřbívalo se na nich až do 18. století (Navrátilová 2004, 277, Unger 2002, 73). Zvláště zámožní měštané si svá místa na městských hřbitovech udržovali. Na nově vzniklých hřbitovech za městskými hradbami bývala pohřbívána především střední vrstva jako byli řemeslníci nebo obchodníci, ale také zemědělci a městská chudina. Tyto hřbitovy však již zpravidla nemívaly vazbu na kostel.

\section{SPECIFICKÉ ZNAKY NOVOVĚKÝCH POHŘBŮ}

Inventář novověkých hrobů je zpravidla tvořen předměty souvisejícími se samotným pohřbem - tedy zbytky rakví a jejich součásti a pozůstatky $\mathrm{z}$ pohřebních oděvů a jejich doplňků. Zvláštní skupinu pak tvoří předměty kladené do hrobů záměrně jako milodary. Takové mívaly např́ílad ochrannou magickou funkci (amulety, rostliny). Vyšší církevní hodnostári, panovníci, šlechta a různí významní představitelé byli navíc vybavováni šperky, odznaky hodnosti a insigniemi, jež tak zdůrazňovaly jejich moc, sociální postavení a majetnost. Hroby duchovních se vyznačují specifickými atributy. Jedná se o kalich (nejčastěji dřevěný), který byl přidáván do hrobu již od středověku. V 17. až 18. století se hroby duchovních dají rozpoznat podle zbytků liturgických oděvů (například mešní roucha), bývá někdy zachována mitra, štola, rukavice apod. Kněz mívá například modlitební knížku, škapulír̆, růženec s kř́ižkem, popř́ípadě s medailonkem. Tyto devocionálie však nejsou kněžskou insignií, nebot' se od 17. století běžně vyskytují v hrobech osob světského stavu. U církevních hodnostář nacházíme religiózní předměty vyšší kvality i nákladnosti (pektorální kříže, prsteny aj.), u ženských příslušnic, například abatyší, to mohou být pozlacené korunky, prsteny a berly. Typickou barokní hrobovou výbavou jsou devocionálie (růžence, medailony, kříže, škapulíře a jiné svátostky) představující navenek křestanské symboly. $\mathrm{V}$ rámci lidové zbožnosti však měly spíše funkci apotropaickou a s touto byly zřejmě i kladeny do hrobů. Jsou kulturním obrazem společnosti 17. až 18. století - dokládají existenci mnoha poutních míst, velkou oblibu kultu světců a díky svým opisům a iko- nografickým námětům poukazují mnohdy na lidové prvky zbožnosti. Růžence s přívěsky bylo obvyklé omotávat kolem zápěstí, poprrípadě vkládat křížky do ruky.

S pohřby v kostele, zvláště u duchovních osob, souvisí také zeměpisná orientace hrobů. Zhruba od 17. století se začali kněží pohřbívat hlavou směrem $\mathrm{k}$ východu, tedy opačně než bylo dosud v katolickém ritu obvyklé. Byl to církevní předpis, obsažený v Rituale Romanum z roku 1614 (Unger 2006, 110). Ten však nebyl striktně dodržován, mnozí kněží byli i nadále pohřbíváni hlavou k západu, tak jako ostatní katolíci. U novověkých kostelů, které měly jinou než západo-východní orientaci, mají i hroby respektující kostel jinou orientaci.

\section{BRNĚNSKÉ HŘBITOVY A NOVOVĚKÉ KOSTELNÍ POHŘBY}

Od stř̌edověku se v Brně pohřbívalo především kolem větších kostelů (srov. Flodrová 1992, 9-12, Hadroušková 1950, 298, Holub et al. 2006, 267-289) (obr. 1). Jeden z nejstarších městských hřbitovů se nacházel u kostela sv. Michala v prostoru dnešní Dominikánské a Starobrněnské ulice. Pohřbívat se zde začalo asi počátkem 13. století, skončilo v 16. až 17. století. Z 13. století pochází hřbitov u kostela sv. Martina na dnešní ulici Benešově (zanikl 1645). Od 13. století existoval hřbitov kolem chrámu sv. Petra a Pavla (zrušen 1785), dále hřbitovy na ulici Kř́žzové při tehdejším kostele sv. Prokopa, na Provaznickém vršku při ústí dnešní Kopečné ulice, kde stával kostel Všech svatých (1258-80. léta 18. století) a na ulici Pekařské (hřbitov při městském špitále s kostelem sv. Ducha; cca 1240-1645). Další špitální hřbitov fungoval na Starém Brně u kostela sv. Anny. Cisterciácký klášter založila Eliška Rejčka v roce 1323, špitál v roce 1331 a od té doby se zde zřejmě pohřbívalo. Doložen je zde však ještě starší hřbitov patřící $\mathrm{k}$ velkofarnímu kostelu (Procházka 2007, 531). Po roce 1300 byl založen hřbitov při minoritském klášteru, mezi dnešními ulicemi Jánská a Minoritská. Pohřbívalo se tam asi do roku 1716. Už od 13. století se pohřbívalo na hřbitově kolem kostela sv. Jakuba, kde pohřbívání pokračovalo minimálně do konce 16 . století; několik pohřbů mohlo být uskutečněno pravděpodobně i později (Holub et al. 2006, 272 ad.). Bylo zde zdokumentováno víc než tisíc pohřbů v několika hrobových horizontech. Pohřby provázely četné devocionální nálezy. Zmíněné hřbitovy fungovaly až do švédského obléhání města Brna v roce 1645, některé až do josefínských reforem na konci 18. století. Přesto koncem 16. století už mnohé hřbitovy nepostačovaly, proto byl založen nový hřbitov (roku 1580) za hradbami města, před tehdejší Veselou bránou. Byl to prostor mezi dnešním Žerotínovým náměstím a ulicí Joštovou. I zde byly zachyceny pohřby v rakvích a s devocionální výbavou. Pochováváni zde byli patrně občané střední sociální vrstvy, drobní řemeslníci, obchodníci, zemědělci i městská chudina, zatímco zámožnější měštané si udržovali hrobová místa u petrského a jakubského chrámu. V 18. století už většina městských hřbitovů nestačila, proto byly zakládány nové hřbitovy ve větší vzdálenosti od města. Zatímco některé starší hřbitovy byly rušeny, jako např́klad hřbitov kolem kostela sv. 


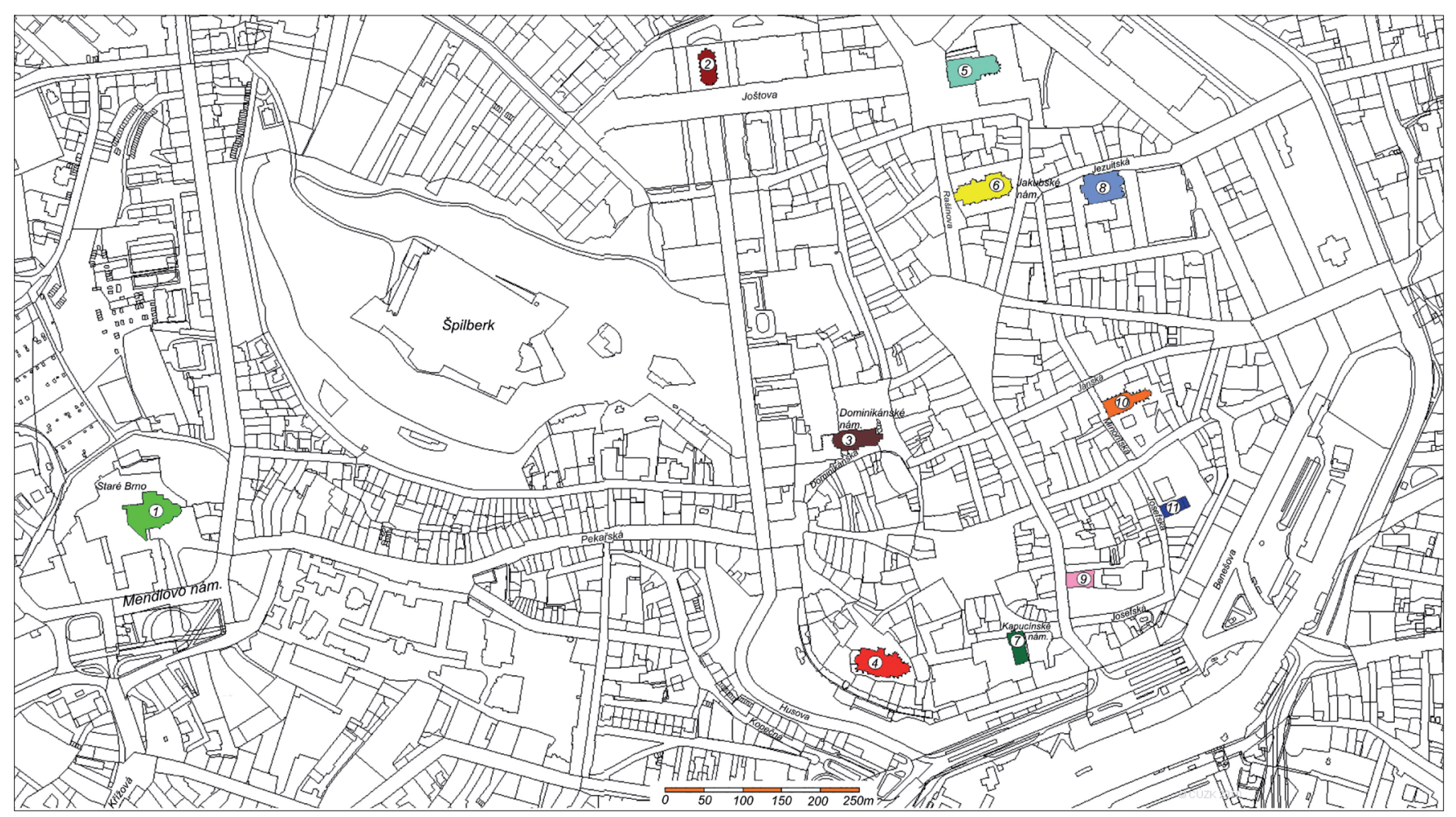

Obr. 1. Výsek mapy z katastrálního území města Brna s vyznačením kostelů v centru města (upravila autorka). 1. Kostel Nanebevzetí P. Marie na Starém Brně, 2. Kostel J. A. Komenského (Červený kostel), 3. Kostel sv. Michala, 4. Katedrála sv. Petra a Pavla, 5. Kostel sv. Tomáše, 6. Kostel sv. Jakuba, 7. Kostel Nalezení sv. Kř́že, 8. jezuitský kostel Nanebevzetí P. Marie, 9. Kostel sv. Máŕí Magdaleny, 10. Kostel sv. Jana Evangelisty a sv. Jana Křtitele, 11. Kostel sv. Josefa.

Petra a Pavla (1785), hřbitov na dnešním Žerotínově náměstí (1785) nebo hřbitov u sv. Václava na Vídeňské ulici (1783), vznikaly od roku 1783 hřbitovy nové, např́klad na dnešní ulici Vranovské a Kounicově (severně od dnešní Antonínské). Posledně jmenovaný hřbitov za hradbami města sloužil tehdy pro celé Brno (jak pro katolické, tak evangelické pohřby). Bylo zde zachyceno přes tisíc pohřbených jedinců opět s výbavou náboženského charakteru (viz Králíková 2007, 111). V následujících letech 19. století byl hřbitov asi čtyřikrát rozšiřen až na dvojnásobek své původní rozlohy. Zrušen byl v roce 1883 . V tomtéž roce byl otevřen dodnes fungující Ústřední hřbitov, který nahradil všechny zmiňované brněnské hřbitovy.

Některé brněnské chrámy byly také archeologicky zkoumány $\mathrm{v}$ interiérech a pohřby $\mathrm{v}$ nich byly zdokumentovány. $\mathrm{V}$ mnoha $\mathrm{z}$ nich se nachází podzemní krypty s ostatky těl dodnes zachovanými. V prvé řadě jsou doloženy pohřby duchovních osob (kněží, opati, kanovníci), pohřby řádových př́slušníků a pohřby významných a majetných laických osob a brněnských obyvatel.

Hrob kněze byl objeven např́íklad v klášterním kostele cisterciaček na Starém Brně. Podle identifikační kovové destičky $(13 \times 11 \mathrm{~cm})$, zasazené kolmo v hrobě za hlavou pohřbeného, bylo zjištěno, že dotyčný zemřel roku 1770. Pohřbený byl orientován hlavou k východu, ležel v rakvi na zádech s rukama sepjatýma na prsou, pod hlavou měl podušku plněnou peřím. Okolo rukou byl ovinut růženec s krucifixem. Zachovaly se i zbytky z dlouhého liturgického oděvu a korálky, které jej zdobily (Novotný 1967b, 58).
Osoby vyššího duchovního stavu byly pohřbívány s větší nákladností a pompou než obyčejní kněží. V novověku zpravidla nacházely své místo odpočinku v kryptách pod kostelními dlažbami či v ambitech klášterů. Kostel sv. Tomáše měl původně sloužit jako pohřebiště moravských markrabat, ale pohřben by zde měl být jen markrabě Jan Jindřich Lucemburský (zakladatel augustiniánského kláštera v roce 1350) a jeho syn Jošt. Ten byl uložen do hrobky v roce 1411. Dále zde měl být v 17. století pohřben fundátor brněnských augustiniánů Jan ze Schambachu a prelát Alfonse Steimose (Maráz 1998, 393). V podzemí se nachází rozlehlá krypta, která sloužila v 18. století především pro pohřby brněnských augustiniánů. Ještě v roce 1860 obsahovala tlející dřevěné rakve, $\mathrm{v}$ nichž se nacházely rozpadlé kosti, zbytky hedvábných látek, soukenných kapucí a několik kožených cingulí (Schram 1896, 32). Hrob opata Mattheuse Bertschera, zemřelého roku 1777, byl objeven v jedné z komor hrobky. Ostatky jeho těla, původně uložené v rakvi, byly orientovány východ-západ. V dobrém stavu zůstala zachována kožená obuv a další kožené součásti oděvu, také mitra, knoflíky a provázek. Zemřelý měl pektorální kříž s Kristem. Identifikován byl podle kovové destičky o rozměrech 14x11 cm (Procházka - Zatloukal 1991).

Hlavní hrobkou v kostele sv. Michala je krypta dominikánů nacházející se před hlavním oltářem. V křížové chodbě tohoto dominikánského kláštera byly údajně do zvláštního výklenku (o rozsahu natažených lidských těl) pohřbíváni dobrodinci kláštera, členové bratrstva jsoucí v nějakém vztahu ke klášteru, a dále př́buzní konventuálů. Tito jedinci byli prý ukládáni 


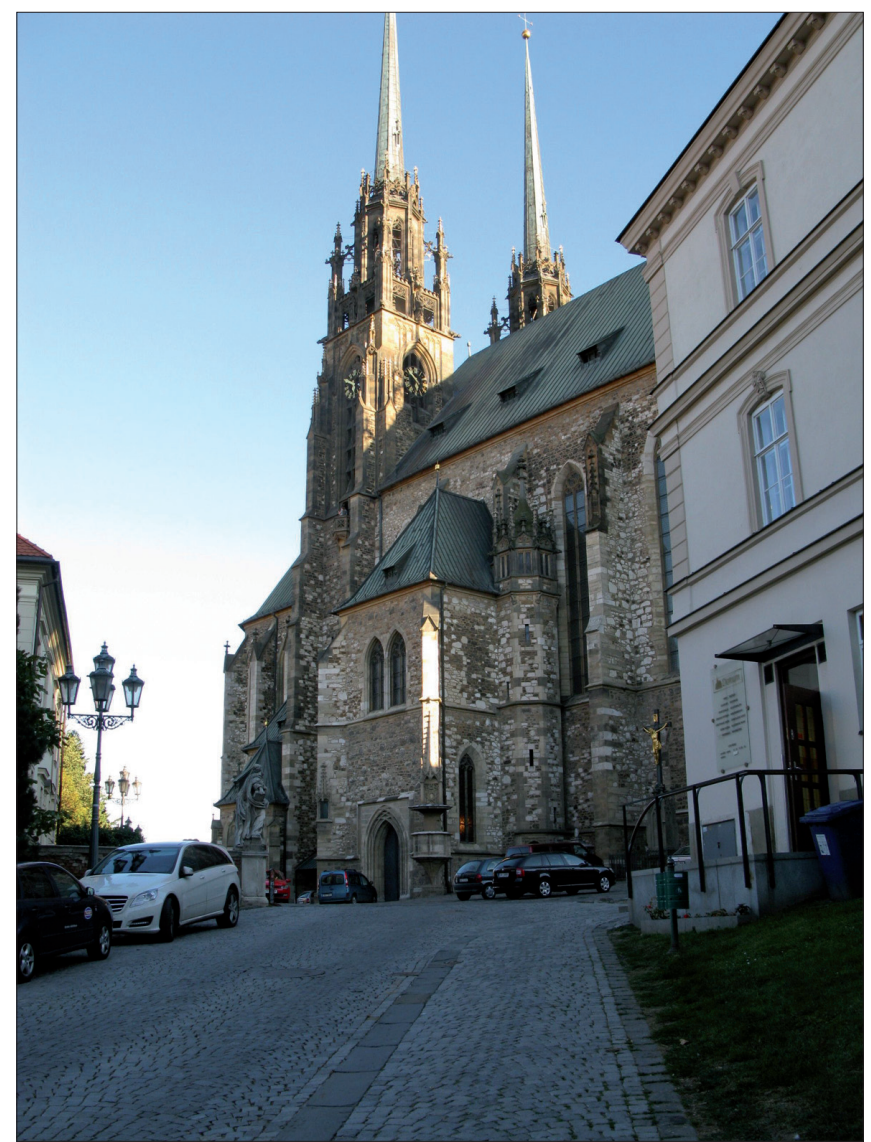

Obr. 2. Katedrála sv. Petra a Pavla v Brně (pohled ze SZ). Foto: Miroslav Králík.

v bílém oděvu a bez rakve (Schram 1896, 38, 40). Při archeologickém výzkumu (2001/2002) byl v západním křídle chodby zdokumentován jeden novověký hrob, v severním křídle bylo odkryto sedm pohřbů; větší část chodby zabíral vchod do barokní krypty. Tři pohřby pocházející ze závěru 16. století byly objeveny při průzkumu kapitulní síně (Holub et al. 2006, 227).

Příkladem krypty, kde spočinuly společně osoby jak duchovního tak světského stavu je kostel Nalezení sv. Kř́žze s přilehlým kapucínským klášterem. Krypta, založená spolu s klášterem roku 1650, zaujímá v podzemí velkou část půdorysu kostela. Zpočátku sloužila jako pohřebiště kapucínským mnichům, kteří jsou dodnes uloženi v nejstarší místnosti krypty. Byli zde pohřbíváni od založení kláštera $\mathrm{v}$ roce 1650 . Tito řádoví příslušníci dodržovali obzvláště uniformní a prostý způsob pohřbívání, jenž symbolizoval skromnost a chudobu tohoto žebravého řádu. Řád kapucínů měl mnoho př́iznivců, kteří si přáli být $\mathrm{v}$ kryptě pohřbeni. Leží v dřevěných barokních rakvích vystlaných hoblinami, z nichž některé mají prosklené víko a jsou ozdobeny malbami náboženských symbolů a motivů smrti. Celkem bylo v kryptě pochováno 205 mrtvých. Vlivem přirozené mumifikace suchým vzduchem se zachovalo 41 těl. Pohřbívalo se zde až do zákazu císaře Josefa II. roku 1784 (Rubinková 1999b, 76-78).

Krypta ze čtyř klenutých prostor se nachází také pod kněžištěm jezuitského kostela Panny Marie. Byli do ní ukládáni řá- doví prř́slušníci. Pohřben je tam také páter Martin Středa, rektor jezuitské koleje. Menší krypta v rohu levé postranní lodi byla pravděpodobně určena pro pohřby terciářu - laických př́slušníků jezuitského kolegia (Schram 1896, 36).

Kostel sv. Jakuba se stal místem odpočinku mimo jiné významného vojevůdce a obránce města Brna před Švédy roku 1645 - Raduita de Souches, který zde byl pohřben roku 1682 vedle těla své manželky. Některé části jeho pohřebního oděvu zůstaly dobře zachovány, pohřben byl údajně s kordem, ostruhami a maršálskou holí (Novotný 1967a, 56-57). Pod dlažbou kostela byla objevena rozsáhlá krypta, sloužící jako kostnice. Také př́slušnice ženských řádů byly pohřbívány v kostelních kryptách. Rakve jeptišek s olověnými destičkami se našly v brněnském kostele sv. Josefa, k němuž náležel přistavěný klášter uršulinek. Jména pohřbených jeptišek byla zapsána v pamětní knize, kdysi uložené v sakristii kostela (Schram 1896, 38). Dominikánské řádové sestry, působící do roku 1782 v ženském klášteře s přilehlým kostelem sv. Anny (později přeměněným v nemocnici u sv. Anny), byly pohřbívány do krypty pod tehdejším kostelem. Nalezeno tam bylo kdysi asi 60 zdobených rakví se zpráchnivělými kostmi a s devocionální výbavou. Objeveno bylo také 13 cínových tabulek z rakví, které pocházely z let 1767-1776 (Schram 1896, 41). Cisterciačkám sloužil k pohřbům do roku 1784 kostel Nanebevzetí P. Marie na Starém Brně.

\section{KATEDRÁLA SV. PETRA A PAVLA}

Tento chrám, zvaný též „Petrov“, leží na návrší nad jižním okrajem historického Brna (obr. 2). Jeho počátky sahají zhruba do konce 12. století. V období gotiky prošel několika přestavbami a byl zvětšen. Jeho význam vzrostl poté, co se roku 1296 stal sídlem kolegiátní kapituly. Kolem roku 1500 bylo původní zasvěcení svatému Petrovi rozšířeno na zasvěcení sv. Petrovi a Pavlovi. Během třicetileté války kostel vyhořel a jeho obnova proběhla ve dvou barokních fázích v letech 1651-1652 a 1743-1746. Roku 1777 bylo bulou papeže Pia VI. potvrzeno zrrízení brněnského biskupství a kostel byl povýšen na katedrálu.

Již ze 13. století je archeologicky doložen v okolí kostela hřbitov, který zde fungoval až do 80 . let 18 . století. Z tohoto období pochází i množství hrobů zachycených v interiéru kostela. Novověkých hrobů bylo při archeologickém výzkumu v letech 1991-1992 odkryto asi 47, z toho 27 hrobů obsahovalo hmotné nálezy poukazující na období 16. až 18. století (viz Rubinková 1999a, díl II.). Jednalo se především o předměty religiózního charakteru, tzv. devocionálie (viz Králíková 2004). Jsou to předměty osobní zbožnosti, které byly oblíbené za života jedince a nezbytné pro pohřeb řádného katolíka. Šlo o růžence (obr. 3) - pomůcky při modlení a rozjímání a na ně zavěšované přídavky $\mathrm{v}$ podobě větších či menších křížků a medailonků (obr. 4). Tyto předměty nesly různá vyobrazení poutních míst a světců s nápisy a opisy. Jejich součástí byly často zaříkací formulky - invokace, mající především apotropaický význam (magický, ochranný). I přes tyto lidové prvky 


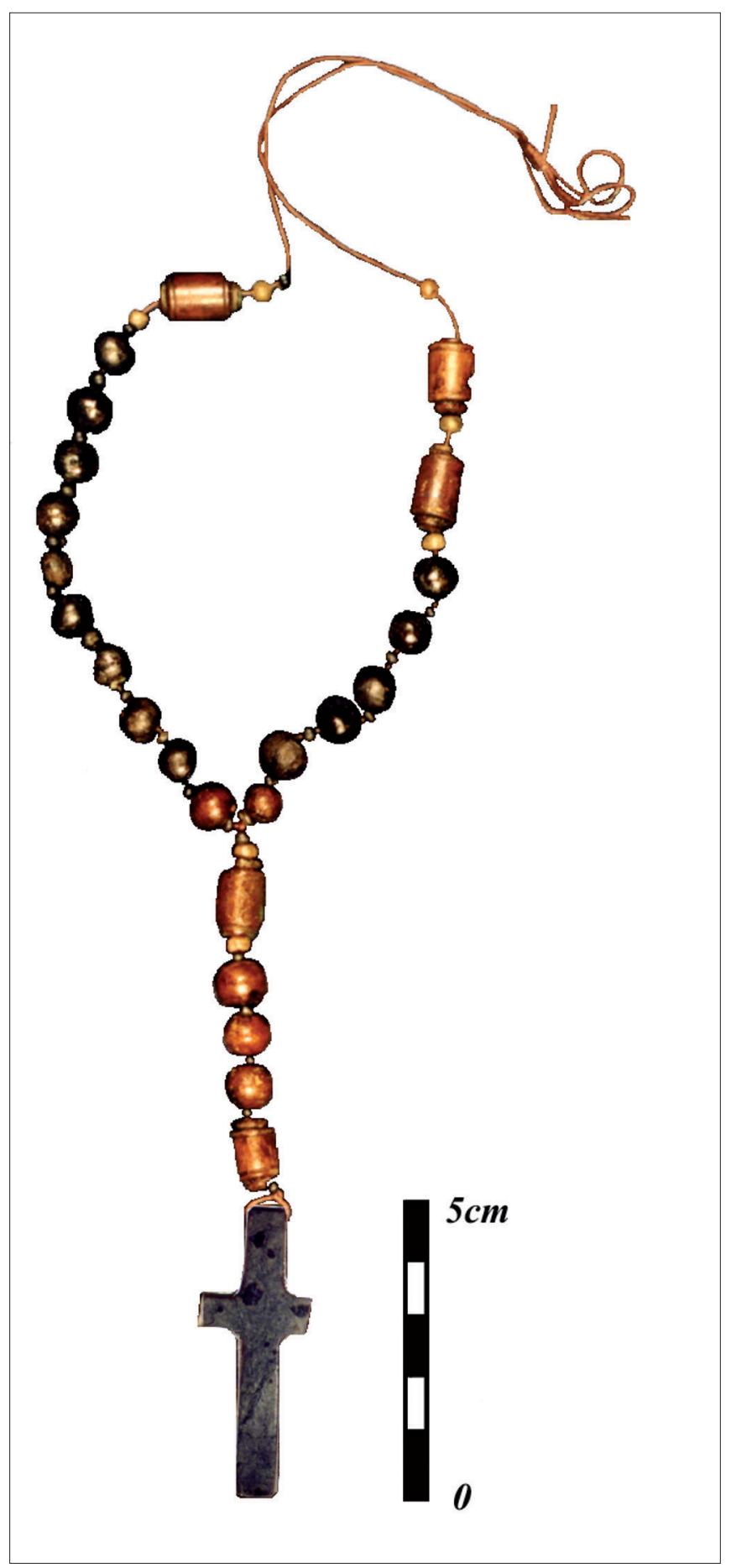

Obr. 3. Růženec s křížkem (katedrála sv. Petra a Pavla v Brně, hrob č. 368, 17.-18. století). Foto: Miroslav Králík.

byly předměty církví přijímány, nebot tak upevňovaly katolické cítění a prožívání zbožnosti, například v podobě poutí. Mrtví zde byli do hrobů uloženi v dřevěných rakvích, v poloze na zádech, s nataženými dolními končetinami a pažemi ohnutými v lokti. Většina pohřbených ležela hlavou k západu, až na čtyři hroby s opačnou orientací. Z nalezené oděvní výbavy hrobů lze soudit, že mrtví byli pohřbíváni v oblečení textilního charakteru (někdy i zdobeného výšivkou), s kožený-



Obr. 4. Medailon s vyobrazením Ježíše Krista a Panny Marie (katedrála sv. Petra a Pavla v Brně, hrob č. 488, 16.-18. století). Foto: Miroslav Králík.

mi doplňky a v botách. Několik zbytků kapucí, nacházených v oblastech lebky, ukazuje na řádový oděv. Podle antropologického rozboru, který provedly Ladislava Horáčková a Lenka Vargová z Lékařské fakulty Masarykovy univerzity v Brně, byli jedinci mužského pohlaví, vyjma tří hrobů, u nichž byl skelet určen jako ženský. Většina jedinců zemřela ve věku maturus (40 až 60 let), pouze ve třech prrípadech bylo určeno stáří adultus (25 až 40 let).

Také $\mathrm{v}$ tomto brněnském kostele se nacházela krypta, a to zhruba ve střední části presbytáře. Vznikla v roce 1747 zapuštěním do krypty raně gotické. Zmínka o barokní kanovnické hrobce pod presbytářem existuje již k roku 1863, kdy byla popsána jako vyzděné sklepení obdélníkového tvaru (Schram $1896,24)$. Sloužila pro pohřby vysoce postavených duchovních, kteří byli členy kolegiátní kapituly. Bylo zde objeveno 16 malovaných rakví s tělesnými ostatky se zbytky oděvů a obuvi. Stejného stář́ jako krypta byla sekundární malá hrobová komora umístěná při jižní stěně presbytáře, která skrývala ostatky zemského hejtmana Ladislava Popela z Lobkovic. Původní místo jeho pohřbu bylo zřejmě v presbytáři, odkud byl hrob přesunut právě $\mathrm{z}$ důvodu stavby kanovnické hrobky.

\section{ZÁVĚR}

Pohřby nalézané uvnitř a v okolí kostelů jsou dokladem dlouhodobých pohřebních zvyklostí, typických pro středoevropskou oblast. Sahají do samotných počátků vzniku sakrálních staveb a jsou svázané především s trendem katolického ritu. Byly především výsadou privilegovaných osob. Charakteristiky pohřbů $v$ různých historických etapách se proměňovaly v souvislosti s měnícím se vnímáním a prožíváním smrti a později také se skutečností, že se do zpưsobu pohřbívání kromě církve začal vkládat i stát. Od 2. poloviny 18. století za- 
čal na úkor kostelních pohřbů narůstat počet hrobů na hřbitovech, což byla předzvěst konce pohřbívání v kostelech. Vládní zákazy a př́kazy však zdá se nebyly dodržovány výlučně a byly přijímány lidovou vrstvou jen pozvolna. Některé zakořeněné zvyklosti vycházející z pohanství místy přetrvávaly až do 19. století. Hmotné nálezy a historické památky Brna dokládají nejen politicko-historický význam této metropole, ale přibližují také některé stránky společenského života a kultury předchozích staletí na Moravě.

\section{LITERATURA}

Ariès, Philippe (2000): Dějiny smrti, I., II. Praha: Argo.

Bednárik, Rudolf (1972): Cintoríny na Slovensku. Bratislava: Vydavatelstvo Slovenské akadémie vied.

Fingerlin, Ilse (1992): Die Grafen von Sulz und ihr Begräbnis in Tiengen am Hochrhein. Stuttgart: Kommissionsverlag - Konrad Theiss Verlag.

Flodrová, Milena (1992): Brněnské hřbitovy: Průvodce po jejich historii, čestných hrobech města Brna, památkově chráněných náhrobcích a vojenských pohrebištích. Brno: Rovnost.

Hadroušková, M. (1950): Hřbitovy a pohřbívání v Brně do r. 1947. Lékařské listy $z$ 15. května, 298-301.

Holub, Petr - Kolařík, Václav - Merta, David - Peška, Marek - Sedláčková, Lenka - Zapletalová, Dana - Zůbek, Antonín (2006): Brněnské středověké a raně novověké hřbitovy $\mathrm{z}$ pohledu archeologie. Brno v minulosti a dnes, XIX, 267-289.

Králíková, Michaela (2004): Devocionálie jako předměty zbožnosti v hrobech ze 17.-19. století. Rigorózní práce. Brno: Katedra antropologie Př́rodovědecké fakulty Masarykovy univerzity.

Králíková, Michaela (2007a): Devocionálie z brněnského hřbitova 18.-19. století jako součást katolického pohřebního ritu. Brno v minulosti a dnes, XX, 111-121.

Kunc, F. J. (1937): Od počátku až do skonání světa. Praha: Spolek Pieta.

Maráz, Karel (1998): Augustiniánský záznam o otevření hrobu moravského markraběte Jošta v roce 1752 a jeho edice. Časopis Matice moravské,117, 393-406.

Navrátilová, Alexandra (1998): Hřbitov jako místo kontaktu dvou světů. Folia ethnographica, 32, 153-161.

Navrátilová, Alexandra (2004): Narození a smrt v české lidové kultuře. Praha: Vyšehrad.

Novotný, Boris (1967a): Vyzvednutí pozůstatků maršála Raduita de Souches, obránce Brna proti Švédům. Přehled výzkumů 1966, 56-57.

Novotný, Boris (1967b): Záchranný výzkum ve starobrněnském kostele a nález hrobky pana Jindřicha z Lipé. Přehled výzkumů 1966, 58-59.

Procházka, Rudolf (2007): Poznámky k brněnským hřbitovům období středověku a raného novověku. Brno v minulosti a dnes, XX, 529-532.
Rubinková, Michaela (1999a): Pohřební ritus 17. a 18. století na Moravě, díl I., II. Diplomová práce. Brno: Katedra antropologie Př́rodovědecké fakulty Masarykovy univerzity.

Rubinková, Michaela (1999b): Kapucínská krypta v Brně. Vlastivědný věstník moravský, 51(1), 76-78.

Schram, Wilhelm (1896): Brünner Kirchengrüfte. Notizenblatte des Vereines für Geschichte Mährens und Schlesiens, 23-46.

Unger, Josef (2002): Pohřební ritus a zacházení s těly zemřelých v českých zemích (s analogiemi i jinde v Evropě) v 1.-16. století. In: Malina, Jaroslav, ed., Panoráma biologické a sociokulturní antropologie 9. Brno: Nauma.

Unger, Josef (2006): Pohřební ritus 1. až 20. století v Evropě z antropologickoarcheologické perspektivy. In: Malina, Jaroslav., ed., Panoráma biologické a sociokulturní antropologie, sv. 25. Brno: Akademické nakladatelství CERM - Nauma.

\section{PRAMENY}

Procházka, Rudolf - Zatloukal, Richard (1991): Brno (okr. Brno-město) - Kostel sv. Tomášse. NZ. Brno: Ústav archeologické památkové péče.

\section{PODĚKOVÁNÍ}

Za pomoc při fotografické dokumentaci děkuji manželu Miroslavovi, za pomoc s anglickým překladem děkuji manželům Ladislavu a Veronice Nejman.

\section{AUTORKA}

Králíková, Michaela (rozená Rubinková, 5. 5. 1976, Brno), česká antropoložka; absolventka magisterského a doktorského studijního programu a rigorózního řízení $\mathrm{v}$ oboru antropologie na Ústavu antropologie Př́rodovědecké fakulty Masarykovy univerzity v Brně. Diplomová práce: Pohřební ritus 17. a 18. století na Moravě (1999), vedoucí práce: Prof. PhDr. Josef Unger, CSc.; rigorózní práce: Devocionálie jako předměty zbožnosti v hrobech ze 17.-19. století (2004), disertační práce: Pohřební ritus 16.-18. století na Moravě a ve Slezsku s prìhlédnutím k území střední Evropy (2006), školitel: Prof. PhDr. Josef Unger, CSc. Pro edici Panoráma biologické a sociokulturní antropologie napsala 35. svazek Pohřební ritus 16.-18. století na území střední Evropy (antropologicko-archeologická studie) (2007).

Kontakt: RNDr. Michaela Králíková, Ph.D., e-mail: misakralik@seznam.cz. 